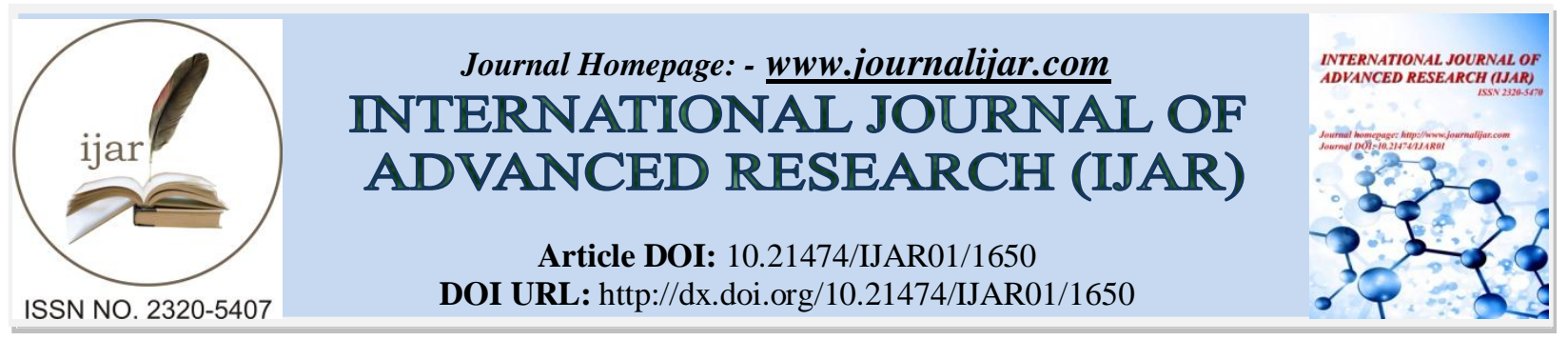

RESEARCH ARTICLE

\title{
LEGAL NATURE OF INTERNATIONAL PRIVATE LAW AND ITS PLACE IN LEGAL SYSTEM.
}

Rakhmankulova Nilufar Khoja-Akbarovna.

Senior science researcher at Tashkent State University of Law.

\section{Manuscript Info}

Manuscript History

Received: 12 July 2016

Final Accepted: 19 August 2016

Published: September 2016

Key words:-

place of international private law in the legal system, international legal nature, national legal nature, independent branch, complex branch, intersystem complex.

\section{Abstract}

This article analyzes the issues of legal nature of international private law and its place in the legal system of the state. In this regard, consider the views of prominent Russian jurists and lawyers of other CIS countries on International Private Law, and is divided into three main concepts regarding the place of private international law in legal system. By being a supporter of the concept of the national nature of private international law as an independent branch of law, fully justified the opinion opinions of other lawyers and practice enforcement rules of international private law.

Copy Right, IJAR, 2016,. All rights reserved.

The question of the legal nature of private international law and its place in the legal system spawned a deep interest in the distant past; this issue is of interest to modern national jurisprudence and now, being the cause of various disputes. This is due to the fact that it occupies a special and specific place in the national legal system.

As in the national and world science of jurisprudence is an ongoing debate on the basis of international private law, the concept of its nature, a place in the common law system, as well as the composition of its norms. Simply put, "how much effort would not have been spent to lift the stone up the hill, in the final analysis, researchers still find themselves at the foot of the mountain and back to the traditional question, we will be forced to start from the beginning: private international law - part of the national law or international law? "1

The doctrine of law in this regard, there are three concepts:

1. International, i.e., the inclusion of private international law in general international law;

2. National, i.e. the inclusion of private international law into domestic national law of each State. Some proponents of this concept include private international law in the civil law, others - recognize it as an independent branch of the national law. Others, in turn, assess private international law as a subsystem of the national legislation;

3. Mixed, i.e. recognition of private international law as a set of international law and national law.

As the founder of the first approach may be noted one of the first Russian scientists in the field of private international law A.N.Stoyanova. As he writes, cases of inherent tensions between foreign laws constitute a "whole section in the science of international law" ${ }^{2}$.

${ }^{1}$ See more. Neshataeva T.N. On the question of the legal system governing international relations // Russian Yearbook of International Law. 1993-1994. - Spb .: Russian-Neva, 1995. - P. 52-53.

${ }^{2}$ Stoyanov A.N. Sketches of history and dogma of international law. / Lectures given at 1873/74 Acad. year at Kharkov University - Kharkov, 1875. - P. 374. 
A.M.Ladyzhensky, in turn, believes that the international norms, the legal regulation of private relations are international public law norms. According to him, they have an international legal character, as set domination of the various states for their use (public dominion), in other words create a public right of one State to other States regarding the right to apply the rules of evidence and require their use ${ }^{3}$.

S.A.Malinin argued that the system of international law (in the broad sense), there are two main independent branch of law: 1) public international law; 2) International Private Law ${ }^{4}$. V.S.Nersesyants also attached to this opinion, and puts forward the idea that "international law is like the internal state law inherent division between" public "and" private ", i.e. International law consists of public international law and private international law " 5 .

One of the supporters of the second approach, including the private international law in the domestic law, I.S.Peretersky, proving the impossibility of incorporating the private international law of the international public law, claims that in most cases private international law rules are determined by individual domestic laws of states. He believes that as a general rule, the specific issues of private international law does not impinge on the mutual relations of the two states ${ }^{6}$. I.S.Peretersky defending his doctrine draws attention to the different meanings of the word "international" in the international public and private international law. According to the author, public international law - international law is in its essence, as establishes the legal relations between States (inter nations, inter gentes), in turn, the private international law - establishes a legal relationship between persons of different states, ie, legal relationships that go beyond the single legal system and requiring a specific definition of the law applicable to the relationship data ${ }^{7}$.

In our view, international law, recognized as a separate legal system, expresses a set of legal rules governing relations between states. In this context, international law (in the broad sense) are aimed at legalization of interstate relations. If you look at the essence of international relations, as well as the relations governed by private international law, it can be seen that they have unique characteristics. The basis of international public relations is the private property, or moral interests of specific individuals. Relations reguliremye international law - this interstate relations. Relations regulated by private international law, mainly operate within the same legal system. Interstate relations, in turn, are of international character. Finally, in the scientific literature when considering the ratio of the analyzed areas of law, the problem of their sources rises. As is well known, as a source of private international law can operate the internal legal act. This criterion can not be applied in respect of international law, as in international law by normotovorchestva method of aligning the freely expressed will of States. Naturally, there are also "common ground" of the analyzed sectors. As such "common ground" can bring the principles that are important for both these branches of law.

One of the scientists who carried out in-depth studies on the legal nature of private international law L.A.Lunts stressed that "Private International Law as a branch of law and jurisprudence is considered to be the industry circle of relations arising in international life, with civil-legal nature in the broadest sense of the word" ${ }^{8}$. Noting that private international law is studying civil law relations, I.S.Peretersky stresses that this fact does not speak about private international law as an integral part of civil law, the specificity of civil relations, members of the private international law is manifested in the fact that private international law is studying a special group of civil relations, with an "international character", while the term "international" is used in this case in a special and conditional sense ${ }^{9}$.

Of course, private international law is closely linked to the civil law, but the international nature of the regulated legal evidence of the error from a theoretical point of view a common approach to their study. Private and

\footnotetext{
${ }^{3}$ Ladyzhenskiy A.M. On the question of the legal nature of the so-called private international law // Bulletin of Moscow University. - 1948. №5. - P. 17.

${ }^{4}$ Malinin S.A. The peaceful use of nuclear energy: International legal questions. - M .: Internat. relations, 1971. P.7.

${ }^{5}$ Getman-Pavlova I.V. Private International Law: Textbook / IV Getman-Pavlova. - Ed. 2nd, Revised. and ext. - M $\therefore$ Eksmo, 2009. - P. 24.

${ }^{6}$ Peretersky I.S. Sketches of the RSFSR of private international law. - M.: State. ed, 1925. -. P.5-6.

${ }^{7}$ Peretersky I.S. The system of private international law // the Soviet state and the right. - 1946. № 8-9. - S. 12-30.

${ }^{8}$ Luntz L.A. The course of private international law. In 3 volumes. A common part. - M. jurid. lit., 1973. -. P.12.

${ }^{9}$ Peretersky I.S., Krylov S.B. Private International Law. - M .: Yurizdat, 1940. - P.5.
} 
international character of the relations regulated by private international law, particularly the method of legal regulation of the subject point to the specifics of the industry. In our view, if we assume that private international law as a subsector of civil law, lost its very important features and characteristics. However, this is - a set of three basic groups of legal relations of a private nature. In addition, such an approach to the problem of lost relationship between the various constituent elements of the legal regulation. "Distribution" of private international law among the different branches of law means giving an objective process in the form of a unified approach to the regulation of the corresponding relations in the modern legal systems.

G.K.Dmitrieva also recognizes private international law as an independent branch of the domestic law, while it claims "Private international law - it is an independent branch in the national legal system. It is part of the system of internal (national) law of the State in this case is not considered in this part of the system of civil, family, labor or private law. Private international law in their specific subject matter and methods of regulation stands as an independent branch of law"10.

Some scientists consider private international law as an integral part of national law, assess private international law as a sub-sector of the national legislation, put forward the idea that "Private International Law, which is considered a small system of law of the Republic of Uzbekistan, is part of a private, partly - public law . The subject of the legal regulation of this small system, are on the one hand, civil, family, labor relations, and on the other hand - the relations arising in the framework of international civil procedure and international commercial arbitration. The subject of this small system distinguishes the integrated approach, as well as its "nadotraslevoy" status" 11 . But, in our view, the legal system is divided only by public and private law system. The complex nature inherent in virtually all areas of law, so the presence of the international private law elements of public law does not lead to its isolation as a separate small system. Even if part of the international private law, there are elements of Public Law, it nevertheless included in the private law. International civil process, in turn, has a particular value in the composition of private international law.

The third approach regarding the legal nature of private international law and its place in the system of law expressed in the understanding of private international law as a set of international law and national law. According to one of the proponents of this approach R.A.Myullersona, "Private international law - it is objectively existing polisistemny complex sostoyashy of complex regulations regarding independent units (including conflict and reference rules as part of national law and international agreements, norms, used as directed by the conflict and reference rules and substantive law, having its own power in the national legal system, as well as international agreements), which do not create "an integrated system, and operate the corresponding" basic "systems of law (national or international law) by adjusting the non-governmental nature of the international relations" ${ }^{\text {"12. }}$. Substantiating his point, R.A.Myullerson, refers to the thoughts of scientists concerning, firstly, the diversity of the material world, and secondly, such a variety of units of at least two types of objective: complete systems and system Complex of. In the second case, the object of the study are not material systems and their base on the objective laws and the system of interdependent activities that exist between objects of different qualities that are in the necessary relationship.

According to the doctrine of private international law, the founder of the third approach is considered A.N.Makarov. According to him, all the contradictions between "internationalists", i.e. supporters of the international legal nature of private international law and "nationalists", recognizing this sector of legal regulation as the domestic law of individual states, is justified for the reason that it comes to filling the gaps in the positive law of conflict. He says, "For me, in particular, the theory corresponding to the current level of international law, is the theory of legal regulation of separateness - international and national. The inevitable inference of the doctrinal point of view is the recognition of separateness conflict of international and national law. Consequently, the gaps of domestic conflicts

\footnotetext{
${ }^{10}$ International private law. Textbook. / Under. Ed. GK Dmitrieva. - M .: Prospect, 2001. - P. 37-38.

${ }^{11}$ Issues of international private law Islands develops prospects. - Tashkent " Adabiyot uchqunlari" publishing group $2014-35$ p.

12 Müllerson RA International public and private international law: the relationship and interaction // Soviet Yearbook of International Law. 1985. - M .: Nauka, 1986. - P. 82.
} 
of law can not be replenished by international legal bases, as well as spaces of international law of conflict can not be solved by legal bases of the individual national systems of conflict "13.

The concept of private international law as "polysystem complex" was supported and T.N.Neshataevoy, in its view, the assertion of legal subdivision of matter into two kinds of legal systems, i.e. on national and international legal system, can not withstand the requirements soveremennyy. Contemporary international relations are so complex and multifaceted (so, they are international, intergovernmental relations), that they can not be resolved only by international public law. Therefore, vozniaket need to review the matter of international law with a systems perspective. This, in turn, makes it possible to identify the legal polysystem - private international law. The author believes that polysystemic private international law is due to the complexity of the regulated public relations. It's a pretty special relationship. Firstly, in terms of content, they are part of the basic social relations of a private nature, within the limits of national law (the civil law); secondly, they are "complicated" foreign or international element (object, subject, legal fact) requiring legal settlement with the application of foreign or international source of law. This source, along with the national rule of law can be in the form of rules of a foreign (international) origin. As a result, the problem of finding a single voznikat mandatory standards. Search can be carried out on the basis of the analogy of legal regulation of conflict norm. As a result, the legal relationship may occur in the first place, based on the set of rules associated with the actual social relations. This complex includes conflict and substantive rules. However, she and the other rules can be both national law and the norms of international agreements ${ }^{14}$.

V.V.Gavrilov also been supporting this approach, putting forward the idea that private international law reflects the polisistemny complex of legal norms of national and international law, for "private international law recognizes the artificial product that can not be considered part of international law as well as part of the internal state law. It does not generate its own system of law, as a member of the standards referred to legal systems ${ }^{\prime 15}$.

According P.Kalenskogo, "Private international law is hesitant to choose between the territorial entity of national law and the universalism of international public law ... It brings in international private law nature of hybridity and expresses it as a very complicated area of law"16. But disagree with the approach danym scientists Yu.K.Tolstoy, V.F.Popondopulo, D.F.Nefedov argue that the complexity of an element common to all branches of law.

In our view, private international law is considered to identify the building blocks of national law. This conclusion is based on two major hypotheses. First, the legal relationship governed by private international law, despite the relationship with the legal systems of other countries are influenced by the system of law of a particular state. In private international law the normal course of the legal regulation provides for such a scenario, where legal regulation is mainly rules of one legal system. However, while other legal systems can not be "indifferent" to the given legal relationship with it having a reciprocal link. For example, this legal framework by defining clause regarding the applicable law, may provide an opportunity to control pravotnosheniya foreign jurisdiction. The argument justifying the affiliation of private international law to the system of national law can be noted the fact that its basic parameters are determined by domestic law. In this sense, private international law borrows its main provisions of national law is.

According N.V.Erpyleva, at the present stage of development of private international law, in view of its legal nature it becomes obvious that his complex character can not be considered private international law within the state (national) right or within a public international law. Private international law - it is absolutely independent branch of law, which has its own subject of legal regulation, different from other legal systems (whether national or international) ${ }^{17}$. N.V.Erpyleva binds "complexity" of private international law to the distinctive features of this

${ }^{13}$ A.N. Makarov The basic principles of private international law. - M.: Legal edition of the People's Commissariat of the RSFSR, 1924. - S. 25, 26.

${ }^{14}$ Neshataeva T.N. On the question of the legal system governing international relations // Russian Yearbook of International Law. 1993-1994. - Spb .: Russian-Neva, 1995. - P. 55.

${ }^{15}$ Gavrilov VV Private International Law: Textbook. - Vladivostok: Publishing house of the Far Eastern University, 1997. - P.13-14.

${ }^{16}$ Getman-Pavlova I.V. Private International Law: Textbook / IV Getman-Pavlova. - Ed. 2nd, Revised. And ext. - M $\therefore$ Eksmo, 2009. - P. 24.

${ }^{17}$ Erpyleva N.V. The concept, subject, system and sources of private international law // International public and private law. - 2002. № 1. - S. 21. 
branch of law, distinguishes it as a separate legal system from the adjacent and related systems of law (public international law and domestic civil law) from the point of independence of special subject (object) method and sources of legal regulation. She writes that "private international law - a complex system of rights that combines norms of domestic public law, international agreements and practices, which by means of collisional-legal and financially-legal methods regulate property and personal non-property relations," complicated "foreign element" ${ }^{18}$.

MKSulejmenov expressing his disagreement with the opinion N.Yu.Erpylevoy regarding recognition of private international law rules of the system, put forward the opposite view, arguing it as follows: "In my opinion, there is no need for the formation of a complex industry in this way, because in addition to the international public law and national law there is no other legal systems. Private international law, despite the presence of the dual nature of the sources, schtaetsya national law. International agreements are part of the national legal system. At the same time, international treaties are a source of public international law and private international law. But, for public international law is irrelevant fact implementation or lack thereof in the domestic law of the state. While private international law governing relations between persons of different countries - is another matter. To control these pravotnosheny, an international agreement have to be implement in domestic law of these states "19.

In our view, private international law is not a separate legal system parallel to the existing national legal system. The grounds for its recognition as a separate legal system is not enough. For the formation of a separate legal system requires a number of factors. Initially, there is a question about the place of such a legal system among the major existing regulatory structures (systems). there are state legal systems in the world today and one standalone system international law. Thus, the study of private international law from the perspective of an independent legal system puts on the agenda the question of its place in the existing legal system. As you know, most of the private international law of each State formed from national sources (regulations, case law, legal practices), this provision, in turn, eliminates the possibility of a common source (hence the formal unity) in the legal system. In our view, the legal system must not only have their legal sources, but also the "special rules". In national legal systems poodobnye problems are solved, as a rule, the constitutional norms. In international law, there are mandatory rules, enrich the content of the following standards - jus cogens. If you look at international private law from that point of view, the search for a unifying factor, "common" for the private international law of all States, is some complexity.

Thus, the specificity of the subject of legal regulation, especially legal sources, as well as the conflict rules that are part of private international law, can serve as the necessary and sufficient basis for the recognition of private international law as an independent branch of national law. We believe the distrust regarding the recognition of private international law as a separate branch of law, largely arisen as a result of the process of codification. In many states, the codification of the rules of private international law was carried out in two ways: the adoption of specific rules on private international law or by the introduction of the conflict rules in sectoral codified acts. Uzbekistan took the path of implementing the conflict of laws rules of the norms of the Civil, Civil Procedure, Economic Procedure, and Family Code. The rules regarding the regulation of private international law relationships also implement a number of legal acts.

International private-legal relations in the fully regulated in the Civil Code, Section VI of the Code referred to as the «Application of the rules of private international law in civil-legal relations» and consist of two chapters: "General" and "conflict rules". It is worth emphasizing that "the existence of a legal act of the general part of the evidence of the fact that these legal norms are distinguished from the legal structure of the complex, their degree of generalization indicates a legal peculiarity of the complex, their special place occupied in the legal system" ${ }^{20}$. It reflects the total of the uniformity, similarity industry regulation subject.

Determining the place of private international law in the system of law of the Republic of Uzbekistan can be concluded about necessary development and adoption of specific legislation on private international law. This, in turn, will contribute to a more systematic and detailed regulation international private law relations, as well as to avoid duplication of standards in legal acts in various industries. In this regard, A.N.Zhiltsov A.I.Muranov and noted that the issue regarding the form "as a whole, is not important, as, in fact, is important, not the form regulates legal

\footnotetext{
${ }^{18}$ Erpyleva NY Private International Law: Textbook for universities. - M .: NOTA BENE, 1999. - P.7.

${ }^{19}$ Suleimenov M. Law as a system: Monograph. - Almaty: Law firm "Zanger", 2011. - 344 p.

${ }^{20}$ Alekseev S.S. General Theory of Law:. The 2-ton V.2. - M .: jurid. lit-ra, 1982. - P.232-233.
} 
acts and their content and mutual correspondence: nevertheless on the basis of simplicity and publicity rules when choosing the form of the act it is advisable to adopt an integrated approach" 21 .

Based on the above analysis of the doctrinal issues concerning the sources of nature and private international law problems showed that the definition of private international law as part of a single set of international law, including international public law and private international law, as well as the doctrine of polysystem private international law weakens its civil nature. First of all, interest is the question of system accessories of private international law. From this perspective, supporters of the two main approaches (except polysystemic) are united in the idea of affiliation of private international law to the internal state law. This suggests that in the national legal systems can be and indeed there are legal frameworks, reflecting the interconnection system of internal relations by means of international private law relations.

Another proof civil nature of private international law lies in the fact that, regardless of the importance and necessity unifications norms of international agreements, is their main source of legislation of the Republic of Uzbekistan. In addition, unlike other separate branches of law, private international law is also inherent in the complex nature. However, he means not polysystemic rights, and the selection of elements of foreign nature of such branches of nationally internal law as civil law, family law, civil procedure law, domestic procedural law, included in the subject of regulation of private international law.

According to Kh-A. Rahmonkulov, "Complex branch of law in its content consists of a set of rules separate branches of law, in the legal system, along with the individual independent branches of the law, there are ancillary or secondary branch of law, consisting of the elements of public and private law ... Complex right in the process of legal regulation is not limited to one method, therefore, can be used the methods of other branches of law regulating legal relations, are the subject of this complex area of law (for example, administrative law, civil law). Therefore, almost all the rules of complex industries nature inherent right to individual branches of law. However, private international law has a special method of legal regulation, is not characteristic of other legal branches. For this reason, the private international law of the vision of the secondary branch of the law is wrong. For private international law - it is a separate branch of law, which has a complex character, is regulated by a special method of legal regulation of the totality of social relations, complicated by foreign element in such branches of national law, as civil law, family law, labor law, civil procedural law, economic - procedural law.

${ }^{21}$ Zhiltsov A.N. Muranov A.I. National codification in contemporary international private law. Trends and contradictions in its development on the threshold of the third millennium // Private International Law: The foreign legislation / Sci. Ed. A.N.Zhiltsov, A.I.Muranov. - M .: Statut, 2001. - P. 36. 